\title{
DISTRIBUTION AND NEW HOST RECORDS FOR COSMOSPORA AURANTIICOLA AND COSMOSPORA FLAMMEA: ENTOMOPATHOGENS OF DIASPIDIDAE IN NEW ZEALAND
}

\author{
J.L. TYSON ${ }^{1}$, R.C. HENDERSON ${ }^{2}$, R.A. FULLERTON ${ }^{3}$, \\ L.E. JAMIESON ${ }^{3}$ and K.J. FROUD ${ }^{4}$ \\ ${ }^{1}$ Ministry of Agriculture and Forestry, PO Box 2526, Wellington, New Zealand \\ ${ }^{2}$ Landcare Research, Private Bag 92170, Auckland, New Zealand \\ ${ }^{3}$ HortResearch, Private Bag 92 169, Auckland, New Zealand \\ ${ }^{4}$ Ministry of Agriculture and Forestry, PO Box 2095, Auckland, New Zealand \\ Corresponding author: tysonj@maf.govt.nz
}

\begin{abstract}
Adventive armoured scale insects (Diaspididae) are of particular concern in New Zealand horticulture due to their polyphagous nature, the damage they can cause, and their implications in biosecurity. Two important species of fungal entomopathogens recorded on armoured scale insects in New Zealand are Cosmospora aurantiicola (Fusarium larvarum) and C. flammea ( $F$. coccophilum). Both have previously been recorded in New Zealand from unidentified Coccoidea; C. aurantiicola has also been recorded on Hemiberlesia lataniae and H. rapax. During 2002-2003, five forays were carried out to provide further information on the host range of the species and to collect strains of the entomopathogens that may have potential as biocontrol agents for armoured scale insects. Aspidiotus nerii, Hemiberlesia sp., Leucaspis brittini, Leucaspis spp., Pinnaspis dysoxyli and Eriococcus cavelli (Eriococcidae) were recorded as new host species for $C$. flammea. Hemiberlesia lataniae is reconfirmed as a host for both species.

Keywords: Cosmospora aurantiicola, Cosmospora flammea, entomopathogen, Diaspididae, New Zealand.
\end{abstract}

\section{INTRODUCTION}

Armoured scale insects (Diaspididae) are a family of highly specialized insects, many of which, e.g. Californian red scale Aonidiella aurantii, greedy scale Hemiberlesia rapax and white peach scale Pseudaulacaspis pentagona, are important agricultural pests. Worldwide they number over 2000 species (Gill 1997).

Armoured scale insects are sapsuckers and may cause loss of vigour, deformation of plant parts, yellowish spots on leaves, loss of leaves and even death of the host plant (Gill 1997; Beardsley \& Gonzalez 1975). Being sessile, colonial and often rather cryptic, many species have invaded new countries with infested plant material and can be a quarantine problem for both importing and exporting countries. This has made them prime targets for biological control programmes using both insect parasitoids and fungal entomopathogens. Unlike other biological control pathogens such as Bacillus thuringiensis (which must be ingested to be effective) fungal entomopathogens can infect their host by penetrating directly through the insect cuticle (Ferron 1978).

Two species of fungal entomopathogens are commonly recorded from armoured scale insects in New Zealand. They are Cosmospora (Nectria) aurantiicola (anamorph Fusarium larvarum) and Cosmospora (Nectria) flammea (anamorph F. coccophilum). Both species are also associated with Diaspididae from warm temperate and tropical 
regions (Rossman \& Samuels 1999), and have been known in New Zealand from 1926 and 1923, respectively (Landcare Research database 2005).

Both of the above species produce orange sporodochia on the surface of infected scale insects. Red perithecia subsequently develop and tend to occur around the edge of the scale caps of diseased insects. Up to 12 perithecia may develop around a single insect (Booth 1971). Porcelli \& Frisullo (1998) found that in Italy C. aurantiicola survived the hot, dry season as mycelium in the dead body of the host, and spread by conidia carried on crawlers. There, the fungus was able to kill about $50 \%$ of scales.

A study was initiated to increase understanding of the two Cosmospora entomopathogens on Diaspididae in New Zealand. The first objective was to obtain new knowledge on the distribution and host range of these fungi within New Zealand. The second objective was to collect new isolates of these entomopathogens, with a view to the identification of new strains as potential biocontrol agents for armoured scale insects. This paper reports the results of the host-range study.

\section{Collection of armoured scale insects}

METHODS

During October 2002-February 2003, five forays were made in search of infected scale insects in the Northland, Auckland, Bay of Plenty, Hawke's Bay and Nelson regions of New Zealand. Random searches were made along or near track margins using foreknowledge of likely scale insect-host plant associations to narrow the target plants, which were then examined with a hand lens. The dates and locations of these collections were as follows:

1. Northland, 25-26 November 2002, 4 sites (Puketi Mokau Reserve; Puhoi Far North Reserve; two commercial citrus orchards; Professor W.R. McGregor Reserve Waipoua).

2. Auckland, 3-8 October 2002, 2 sites (Olive Davis Scenic Reserve, Manurewa; Dairy Flat).

3. Bay of Plenty, 23-24 October 2002, 6 sites (commercial macadamia orchard; Waioeka Gorge $5.1 \mathrm{~km} \mathrm{~S}$ of AroAro Bridge; Kohi Point Walkway between Ohope Beach \& Whakatane; Kaiate Falls; McLaren Falls; McLaren Falls Park at the entrance to Waterfall Bush Walk).

4. Hawke's Bay-Taupo, 6-8 November 2002, 6 sites (Maraetotara Falls; Mohi Bush Maraetotara; Maraetotara Gorge Scenic Reserve; Elsthorpe Scenic Reserve; Blowhard Bush Kaweka Ra; Waituhi Saddle Lookout).

5. Northwest Nelson (10-15 February 2003), 3 sites (Eves Valley Scenic Reserve; Kaihoka Lakes Scenic Reserve; Payne's Ford Scenic Reserve Takaka). Other sites visited and searched were Hawke's Lookout on Takaka Hill, Harwood's Hole track, Pupu Springs Reserve, Wainui Falls track, Pigeon Saddle, the Cobb Valley, and Flora Saddle.

In addition to the scales collected on these forays, one sample of infected scale insects was collected by N. Martin (Crop \& Food Research) on 5 November 2002 from Hinewai Reserve, Banks Peninsula, Canterbury.

\section{Collection and identification of scale insects}

Infected scale insects were most often found on trunks and branches of host trees and were removed by cutting out small pieces of bark, which were placed in paper bags and kept cool for return to the laboratory. Uninfected scale insects from the same site were collected for identification, preserved in $75 \%$ ethanol before slide-mounting, and then identified to species by comparing with specimens in the New Zealand Arthropod Collection (NZAC). The slides were deposited in the NZAC.

\section{Identification of entomopathogens}

Fungi from infected scales were isolated into pure culture by transferring small portions of sporodochia or perithecia on to potato dextrose agar (PDA) modified with streptomycin sulphate $(100 \mu \mathrm{g} / \mathrm{ml})$ and ampicillin $(250 \mu \mathrm{g} / \mathrm{ml})$ to inhibit bacterial growth. The isolated fungi were identified by the formation and shape of the conidia, culture characteristics 
and growth rates at $25^{\circ} \mathrm{C}$ and $30^{\circ} \mathrm{C}$ on PDA (Booth 1971). Cultures of $C$. aurantiifolia and $C$. flammea isolated from diseased insects are held in $-80^{\circ} \mathrm{C}$ storage at the Mt Albert Research Centre of the Horticulture and Food Research Institute of New Zealand.

\section{RESULTS AND DISCUSSION}

Previous host records (worldwide) of Cosmospora aurantiicola and C. flammea are shown in Tables 1 and 2, respectively.

TABLE 1: Host records and common names for Cosmospora aurantiicola (anamorph Fusarium larvarum) recorded worldwide. Note that records include the synonyms Nectria aurantiicola and Sphaerostilbe aurantiicola.

\begin{tabular}{|c|c|c|c|}
\hline Host & Common name & Reference & $\begin{array}{c}\text { Found in } \\
\text { current } \\
\text { survey? }\end{array}$ \\
\hline Aonidiella aurantii & California red scale & Moore 2002 & No \\
\hline Chionaspis heterophyllae & pine needle scale & ScaleNet database 2005 & No \\
\hline Chrysomphalus aonidum & Florida red scale & Moore 2002 & No \\
\hline Diaspidiotus ostreaeformis & oystershell scale & Hornok \& Kozar 1984 & No \\
\hline Diaspidiotus perniciosus & San Jose scale & $\begin{array}{l}\text { CMI Descriptions } \\
\text { 1981a }\end{array}$ & No \\
\hline Hemiberlesia lataniae & latania scale & $\begin{array}{l}\text { Landcare Research } \\
\text { database } 2005\end{array}$ & No \\
\hline Hemiberlesia rapax & greedy scale & $\begin{array}{l}\text { Landcare Research } \\
\text { database } 2005\end{array}$ & No \\
\hline Hemiberlesia sp. & - & - & Yes \\
\hline Lepidosaphes beckii & purple scale & ScaleNet database 2005 & No \\
\hline Lepidosaphes gloverii & Glover scale & ScaleNet database 2005 & No \\
\hline Leucaspis sp. & - & - & Yes \\
\hline Melanaspis obscura & obscure scale & ScaleNet database 2005 & No \\
\hline Pseudaonidia duplex & camellia scale & Hsiao \& Hsu 1985 & No \\
\hline Suturaspis archangelskyae & almond scale & Cozzi et al. 2002 & No \\
\hline Tagionia vitis & black oak scale & $\begin{array}{l}\text { Baldacchino \& de } \\
\text { Corato } 2004\end{array}$ & No \\
\hline $\begin{array}{l}\text { Unaspis citri } \\
\text { unidentified }\end{array}$ & $\begin{array}{l}\text { citrus snow scale } \\
\text { - }\end{array}$ & ScaleNet database 2005 & $\begin{array}{l}\text { No } \\
\text { Yes }\end{array}$ \\
\hline
\end{tabular}

In the current study, Cosmospora aurantiicola was found on Hemiberlesia sp., Leucaspis sp. and several unidentified Diaspididae. In this survey it was only found in the Auckland, Bay of Plenty and Gisborne regions. Previous surveys also recorded this species from Hemiberlesia lataniae in Northland (J. Charles, pers. comm.).

Cosmospora flammea was found on Aspidiotus nerii, Hemiberlesia lataniae, Hemiberlesia sp., Leucaspis brittini, Leucaspis sp., Pinnaspis dysoxyli and several unidentified Diaspididae. It was also found on Eriococcus cavelli, the first time this pathogen has been recorded from Eriococcidae. This species was found in the Auckland, Bay of Plenty, Canterbury, Hawke's Bay-Taupo and Northland regions.

Host-plant associations of the scale insects included Actinidia sp., Alectryon excelsis (titoki), Aristotelia serrata (wineberry), Brachyglottis repanda, Carmichaela australis, Carpodetus serratus, Coprosma grandifolia, Dysoxylum spectabile, Hoheria populnea, Macadamia sp., Macropiper excelsum, Melicytus ramiflorus (mahoe), Myrsine australis, Nothofagus fusca, Ulex europaeus (gorse), Vitex lucens (Puriri) and Salix X reichardtii (pussy willow). 
TABLE 2: Host records and common names for Cosmospora flammea (anamorph Fusarium coccophilum) recorded worldwide. Note that records include the synonym Nectria flammea.

\begin{tabular}{lllc}
\hline & & & $\begin{array}{c}\text { Found in } \\
\text { current } \\
\text { survey? }\end{array}$ \\
\hline Host & Common name & Reference & No \\
Aonidiella aurantii & laurel scale & ScaleNet database 2005 & No \\
Aonidiella citrina & California red scale & Gao \& Ouyang 1981 & No \\
Aspidiotus destructor & yellow scale & Gao \& Ouyang 1981 & No \\
Aspidiotus nerii & coconut scale & ScaleNet database 2005 & Yes \\
Chrysomphalus aonidum & Oleander scale & CMI Descriptions 1981b & No \\
Diaspidiotus peniciosus & San Jose scale & Gao \& Ouyang 1981 & ScaleNet database 2005 \\
Hemiberlesia lataniae & latania scale & ScaleNet database 2005 & Yes \\
Hemiberlesia sp. & - & - & Yes \\
Hemiberlesia rapax & greedy scale & CMI Descriptions 1981b & No \\
Leonardianna pimentae & - & ScaleNet database 2005 & No \\
Leucaspis brittini & - & - & Yes \\
Leucaspis sp. & - & - & Yes \\
Melanaspis obscura & obscure scale & ScaleNet database 2005 & No \\
Pinnaspis dysoxyli & - & - & Yes \\
Pseudaonidia duplex & camellia scale & ScaleNet database 2005 & No \\
Pseudaonidia trilobitiformis & trilobite scale & ScaleNet database 2005 & No \\
Pseudaulacaspis pentagona & white peach sale & CMI Descriptions 1981b & No \\
Unaspis yanonensis & arrowhead scale & Gao \& Ouyang 1981 & No \\
unidentified & - & - & Yes \\
\hline & & &
\end{tabular}

Aspidiotus nerii, Hemiberlesia sp., Leucaspis brittini, Leucaspis spp., Pinnaspis dysoxyli and Eriococcus cavelli (Eriococcidae) can be recorded as new host species for C. flammea. Hemiberlesia lataniae is reconfirmed as a host.

The study has shown that $C$. flammea and $C$. aurantiicola are widespread throughout the country and are capable of infecting both native and introduced species of Coccidae. Although it is not possible to assess from this study the extent to which populations of scale were infected, the ease with which they were found suggests that the suppression of colonies in the wild may be significant. Cosmospora flammea was the more prevalent of the two species. It has a wider host range than C. aurantiicola and is distributed more widely throughout the country. The latter species was confined to the warmer parts of New Zealand suggesting that it is less adapted to cool conditions than C. flammea.

Accessions of both species are currently being screened for pathogenicity to Hemiberlesia lataniae, H. rapax and Aspidiotus nerii to assess their potential for commercial development as biological control agents.

\section{ACKNOWLEDGEMENTS}

This work was funded by the Foundation for Research, Science and Technology. We wish to thank all the orchardists who allowed access to their land, the Department of Conservation and local councils. 


\section{REFERENCES}

Baldacchino F, de Corato U 2004. Activity of Fusarium larvarum Fuckel as a natural biocontrol agent of Targionia vitis (Signoret) (Rhynchota: Diaspididae) in Apulia. Informatore Fitopatologico 54(9): 52-56.

Beardsley JW, Gonzalez RH 1975. The biology and ecology of armored scales. Annual Review of Entomology 20: 47-73.

Booth C 1971. The Genus Fusarium. Commonwealth Mycological Institute, United Kingdom. 237 p.

CMI Descriptions 1981a. Commonwealth Mycological Institute Descriptions of Pathogenic Fungi and Bacteria (Fusarium coccophilum) Set 72: Sheet 715.

CMI Descriptions 1981b. Commonwealth Mycological Institute Descriptions of Pathogenic Fungi and Bacteria (Fusarium larvarum) Set 72: Sheet 714.

Cozzi G, Stornelli C, Moretti A, Logrieco A, Porcelli F 2002. Field evaluation of Fusarium larvarum formulations in the biocontrol of Saissetia oleae on olive in Apulia. Acta Horticulturae 586: 811-814.

Ferron P 1978. Biological control of insect pests by entomogenous fungi. Annual Review of Entomology 3: 409-442.

Gao RX, Ouyang Z 1981. A preliminary investigation on parasitic fungi on citrus pests. Weishengwuxue Tongbao 8(2): 57-58.

Gill RJ 1997. The Scale Insects of California: Part 3. The Armored Scales (Homoptera: Diaspididae). California Deptartment of Food \& Agriculture, Sacramento, CA. $307 \mathrm{p}$.

Hornok L, Kozar F 1984. Fungi associated with a scale-insect, Quadraspidiotus ostreaeformis (Curtis, 1843) (Homoptera, Coccoidea: Diaspididae). Acta Phytopathologica Academiae Scientiarum Hungaricae 19(1/2): 9-11.

Hsiao SN, Hsu TC 1985. The infectivity of the red-headed scale fungus, Sphaerostible aurantiicola (B. \& Br.) Petch to the camellia scale, Pseudaonidia duplex Cockerell. Plant Protection Bulletin, Taiwan 27(4): 389-399.

Landcare Research database 2005. http://nzfungi.landcareresearch.co.nz/html/mycology. asp (viewed 15 February 2005).

Moore SD 2002. Entomopathogens \& microbial control of citrus pests in South Africa: a review. South Africa Fruit Journal 1(3): 30-32.

Porcelli F, Frisullo S 1998. The fungus Nectria aurantiicola Berk. et Br. (Fusarium larvarum Fuckel) a biocontrol agent of the armoured scale Suturaspis archangelskyae (Lindinger) in Apulia (southern Italy). Entomologica 32: 109-119.

Rossman AY, Samuels GJ, Rogerson CT, Lowen R 1999. Genera of Bionectriaceae, Hypocreaceae and Nectriaceae (Hypocreales, Ascomycetes). Studies in Mycology 42: $248 \mathrm{p}$.

ScaleNet database 2005. http://198.77.169.79/scalenet/scalenet.htm (viewed 15 February 2005). 